\title{
Změna uspořádání pracoviště za účelem zvýšení objemu výroby
}

\author{
Filip Rybnikár ${ }^{1}$, Jana Kleinová ${ }^{1}$ \\ ${ }_{1}$ Západočeská univerzita v Plzni, Fakulta strojní, Katedra průmyslového inženýrství a \\ managementu \\ Univerzitní 8, 306 14, Plzeň, Česká republika \\ rybnikar@kpv.zcu.cz \\ kleinova@kpv.zcu.cz
}

\begin{abstract}
Anotace: Článek je zaměřen na návrh nového prostorového uspořádání výrobní jednotky. Pro realizaci změny prostorového uspořádání bylo nutné provést prvotní analýzu současného stavu, nalézt nedostatky na pracovišti a stanovit kritéria pro budoucí hodnocení. Na základě analýzy byly vytvořeny varianty nového prostorového uspořádání. Následně jsou varianty hodnoceny a vybrána nejlepší. Závěrem je tato varianta porovnávána s původním stavem na pracovišti.
\end{abstract}

\section{1 Úvod}

Článek se zabývá návrhem nového prostorového uspořádání pracoviště pro společnost, která požaduje zvýšení objemu výroby na tomto pracovišti.

Správný návrh není možné vytvořit bez vstupních dat, která je nutné získat analýzou současného stavu. Součástí analýzy je definice základních faktorů, které významně ovlivňují produktivitu výroby. Těmito faktory je nutné se $\checkmark$ dalších fázích projektování důkladně zabývat a nový návrh přizpůsobit jejich zlepšení. Pro zlepšování je nutné vytvořit nové varianty uspořádání, následně je porovnat a vyhodnotit prínosy. Hodnocení je prováděné hodnotícími metodami, na základě kterých je zvolena vhodná varianta. Pro tuto práci je podstatná metoda multikriteriální, pomocí které byly návrhy hodnoceny v jednotlivých kritériích a následně zvolena nejvhodnější.

Návrh a tvorba nového prostorového uspořádání se řídí určitými zásadami. Cílem je tedy nalézt a navrhnout takové prostorové uspořádání pracoviště, které bude mít významný vliv na zvýšení produktivity a objemu výroby výrobní jednotky. Návrhy prostorového uspořádání jsou tvořeny $v$ software visTable, díky kterému je možno grafické znázornění návrhu ve $2 D$ výkresu i $3 D$ vizualizaci. Vhodná varianta je $v$ závěru porovnána $s$ původním stavem pro ověření prínosů a rozhodnutí, zda bude návrh zaveden do výroby.

\section{$2 \quad$ Metodika}

Práce byla prováděna dle klasických metodik pro návrh a tvorbu prostorového uspořádání pracoviště. $V$ první části byla provedena analýza vstupních dat pro tvorbu koncepce projektu a následující kroky tvořily samotný návrh a 
vizualizaci $v$ software visTable. Návrhy byly hodnoceny multikriteriálním hodnocením a následně porovnány.

\subsection{Analýza vstupních dat}

$\checkmark$ této části byla provedena analýza výrobní jednotky, výrobního programu a výrobkové základny. Výrobní program a základna byly analyzovány dle pozorování a dle komunikace s podnikem. Pro analýzu pracoviště byla využita prostorová studie $v$ několika dílčích krocích pomocí spaghetti diagramu, rozměřením haly, tvorbou $2 \mathrm{D}$ výkresu a zanesením materiálových toků. Následovala časová studie činností pracovníka pomocí snímku pracovního dne a časové využití strojů.

\subsection{Stanovení hodnotících kritérií}

Na základě analýzy byly definovány nedostatky na pracovišti a dle nich byla stanovena kritéria hodnocení jednotlivých variant. Kritéria byla volena měřitelná i neměřitelná, která byla posuzována dle kvalitativního posouzení. Dále jsou jak kritéria maximalizační, u kterých bylo požadavkem dosáhnout vyšších hodnot, tak kritéria minimalizační, u kterých naopak nižších hodnot. Pro stanovení důležitosti kritérií bylo využito metody párového porovnání. Metoda pracuje na principu stanovení pořadí kritérií od nejdůležitějšího po nejméně důležité. Po stanovení pořadí důležitosti je možné vypočíst nenormované váhy kritérií pro určení, kolikrát je kritérium významnější než ostatní kritéria, dle následujícího vzorce (1) [1]:

$$
K_{i}=n+1-p_{i}
$$

$K_{i}$ - nenormovaná váha i-tého kritéria

$n$ - počet kritérií

$p_{i}$ - pořadí i-tého kritéria

Pro procentuální vyjádření důležitosti kritérií byla stanovena normovaná váha kritéria dle (2) [1]:

$$
V_{i}=\frac{K_{i}}{\sum_{i=1}^{n} K_{i}}
$$

$V_{i}$ - normovaná váha i-tého kritéria

$K_{i}$ - nenormovaná váha i-tého kritéria

$n$ - počet kritérií

\subsection{Tvorba návrhů prostorového uspořádání}

Návrhy prostorového uspořádání byly tvořeny sohledem na odstranění zjištěných nedostatky z prvotní analýzy. Cílem bylo zavedení nápravných opatření k nedostatkům a dosažení zlepšení v rámci stanovených kritérií. 


\subsection{Výsledné hodnocení variant}

Hodnocení variant bylo provedeno metodou pořadové funkce, pomocí níž je určeno pořadí variant. Nejvyšší hodnotu pořadové funkce má nejlepší varianta $v$ daném kritériu. Hodnocení je provedeno dle (3) [2]:

$$
w_{t}=\sum_{K=1}^{n} V_{i} * g_{r}\left(x_{t}\right)
$$

$\mathrm{w}_{\mathrm{t}}$ - hodnota pořadové funkce

$\mathrm{V}_{\mathrm{i}}$ - váha důležitosti kritéria

$g_{r}\left(x_{t}\right)$ - hodnota prířazené pořadové funkce

\section{Výsledky}

Tento článek je tvořen na základě skutečně prováděného projektu pro podnik, který požadoval zvýšení objemu výroby na pracovišti prípravy a dělení materiálu. Podnik také předpokládal rostoucí objem výroby $v$ následujících obdobích, a proto byly společností provedeny požadované kapacitní propočty, které byly porovnány se současně dostupnými. Bylo zjištěno nedostatečné kapacity pro budoucí výrobu, proto podnik provedl investici v podobě nákupu 2 nových dělících zařízení, přičemž nejstarší a nejporuchovější stroj z původních z pracoviště odstraní. Při tvorbě návrhu bylo tedy nutné prìhlédnout $k$ tomuto faktu a jako vstup pro návrhy uvažovat celkem 4 dělící zařízení. Celkem byly vytvořeny 3 varianty nového prostorového uspořádání.

\subsection{Analýza současného stavu}

Pracoviště se nachází v hale složené ze dvou lodí, z nichž pouze v jedné jsou dělící zařízení.

\subsubsection{Prostorová studie}

Z prostorové studie bylo zjištěno, že na pracovišti jsou problémy týkající se překonávání dlouhých vzdáleností při manipulaci materiálu a také při přechodech pracovníka. Pracovník manipuluje dlouhé a těžké 6 metrové tyče z lodě výrobní haly, kde nejsou stroje a tuto práci provádí zpravidla ručně. Dalším nedostatkem je tedy nejen špatná ergonomie pracoviště, ale i nedodržení bezpečnosti z hlediska velikosti manipulačních zón na pracovišti. Stroje jsou také nevhodně orientované a dopravníky, které k nim přiléhají, jsou orientované ven z haly, což opět znesnadňuje obsluze práci. Výsledný výkres stanovený pozorováním na pracovišti, rozměřením haly a provedením spaghetti diagramu je vidět na obrázku 1. 


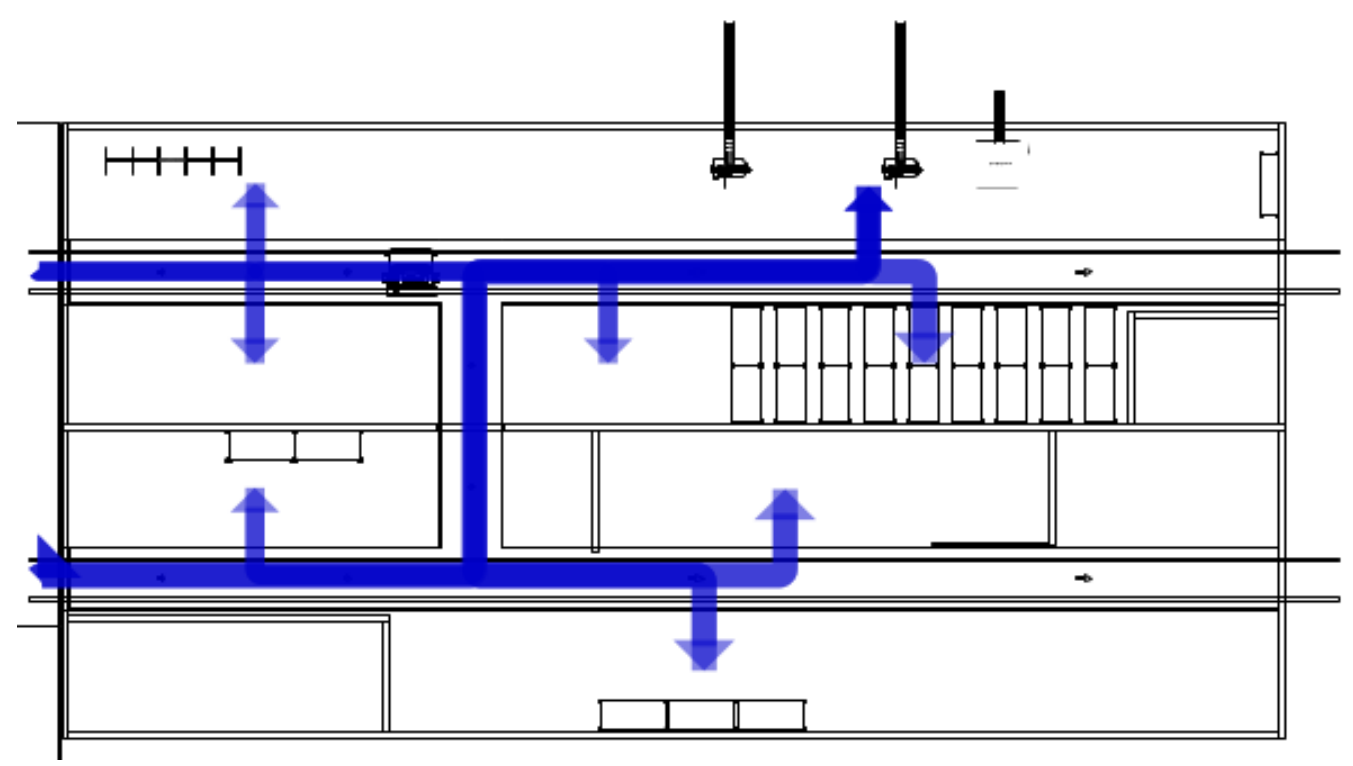

Obrázek 1-2D výkres haly včetně materiálových a personálních toků

\subsection{2 Časová studie}

Výsledky snímků pracovního dne úzce souvisí s výsledky prostorové studie. Výrazný podíl času zaujímají právě zdlouhavé manipulace materiálu. Velký podíl času připadá také na přechody pracovníka do buňky mistra pro vytištění zakázky, hledání materiálu $v$ regálech, přechody ven k dopravníkům a především na čekání u stroje, prič̌emž další stroj v danou chvíli neběžel. Tyto činnosti jsou zavedené jako organizační ztráty a bylo zjištěno, že ani kapacity strojů nejsou plně využité. Výsledek Ize vidět na obrázku 2.

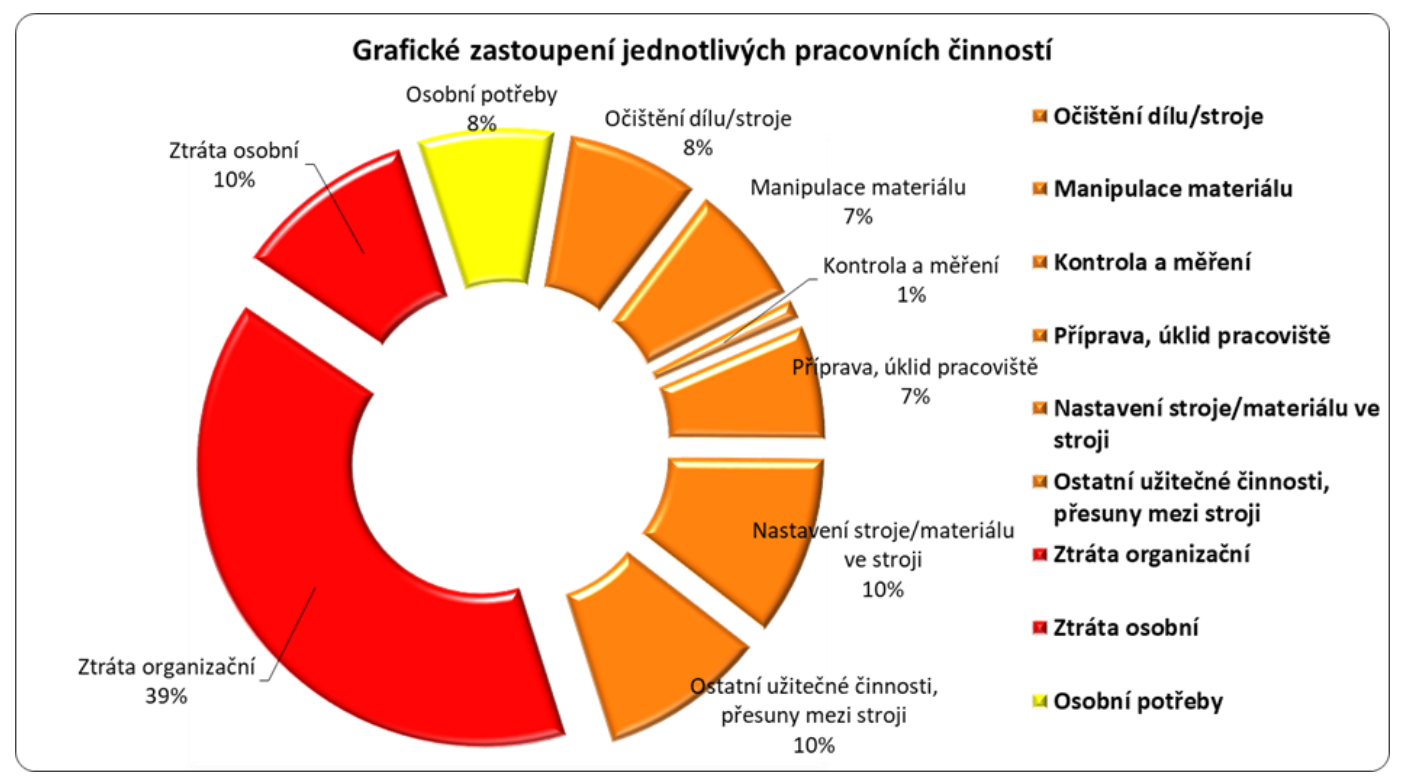

Obrázek 2 - Grafické zastoupení pracovních činností pracovníka

\subsection{Stanovení kritérií}

Volba kritérií vychází z analýzy současného stavu a z vypozorovaných problémů. Tato kritéria jsou znázorněna $v$ tabulce 1. 
Tabulka 1 - Jednotlivá kritéria včetně popisu

\begin{tabular}{|c|c|c|}
\hline Název kritéria & $\mathrm{K}$ & Popis kritéria \\
\hline $\begin{array}{l}\text { Délka materiálového } \\
\text { toku }\end{array}$ & $\mathrm{K}_{1}$ & $\begin{array}{l}\text { Minimalizační kritérium, cílem je dosažení co } \\
\text { nejmenší hodnoty materiálové toku. }\end{array}$ \\
\hline $\begin{array}{c}\text { Délka personálního } \\
\text { toku }\end{array}$ & $\mathrm{K}_{2}$ & $\begin{array}{l}\text { Minimalizační kritérium, cílem je dosažení co } \\
\text { nejmenší hodnoty personálního toku. }\end{array}$ \\
\hline Manipulační zóny & $\mathrm{K}_{3}$ & $\begin{array}{l}\text { Max. kritérium, cílem je dosažení nejvhodnějšího } \\
\text { uspořádání z hlediska dodržení manipulačních zón } \\
\text { a zároveň nezabrat velké plochy výrobní jednotky. }\end{array}$ \\
\hline Organizace práce & $\mathrm{K}_{4}$ & $\begin{array}{l}\text { Max. kritérium, cílem je dosažení vhodné } \\
\text { organizace práce z hlediska rozdělení činností } \\
\text { pracovníka a zavedení vícestrojové obsluhy. }\end{array}$ \\
\hline $\begin{array}{l}\text { Využití kolejnic pro } \\
\text { manipulaci materiálu }\end{array}$ & $\mathrm{K}_{5}$ & $\begin{array}{l}\text { Max. kritérium, cílem je vyšší využití kolejnic pro } \\
\text { zlepšení manipulace při zavážení materiálu. }\end{array}$ \\
\hline $\begin{array}{l}\text { Využití jeř́ábu pro } \\
\text { manipulaci materiálu }\end{array}$ & $\mathrm{K}_{6}$ & $\begin{array}{l}\text { Max. kritérium, cílem je vyšší využití jeřábu pro } \\
\text { zlepšení manipulace při zavážení materiálu. }\end{array}$ \\
\hline Náklady & $\mathrm{K}_{7}$ & $\begin{array}{l}\text { Minimalizační kritérium, cílem je dosažení co } \\
\text { nejmenších nákladủ na reorganizaci pracoviště. }\end{array}$ \\
\hline
\end{tabular}

\subsection{Návrhy uspořádání výrobní jednotky}

Návrhy na nové prostorové uspořádání výrobní jednotky byly tvořeny na základě nápravných opatření definovaných $\mathrm{k}$ jednotlivým nedostatkưm na pracovišti. Cílem bylo dosažení co největšího hodnocení v rámci zvolených kritérií.

\subsubsection{Varianta A - stroje za sebou}

První varianta spočíá ve změně orientace strojů a dopravníků knim přilehlých. Pro uskutečnění tohoto návrhu je třeba pouze přesunu 1 regálu a tímto dojde k úspoře přechodů ven z haly. Návrh je zobrazen na obrázku 3. 


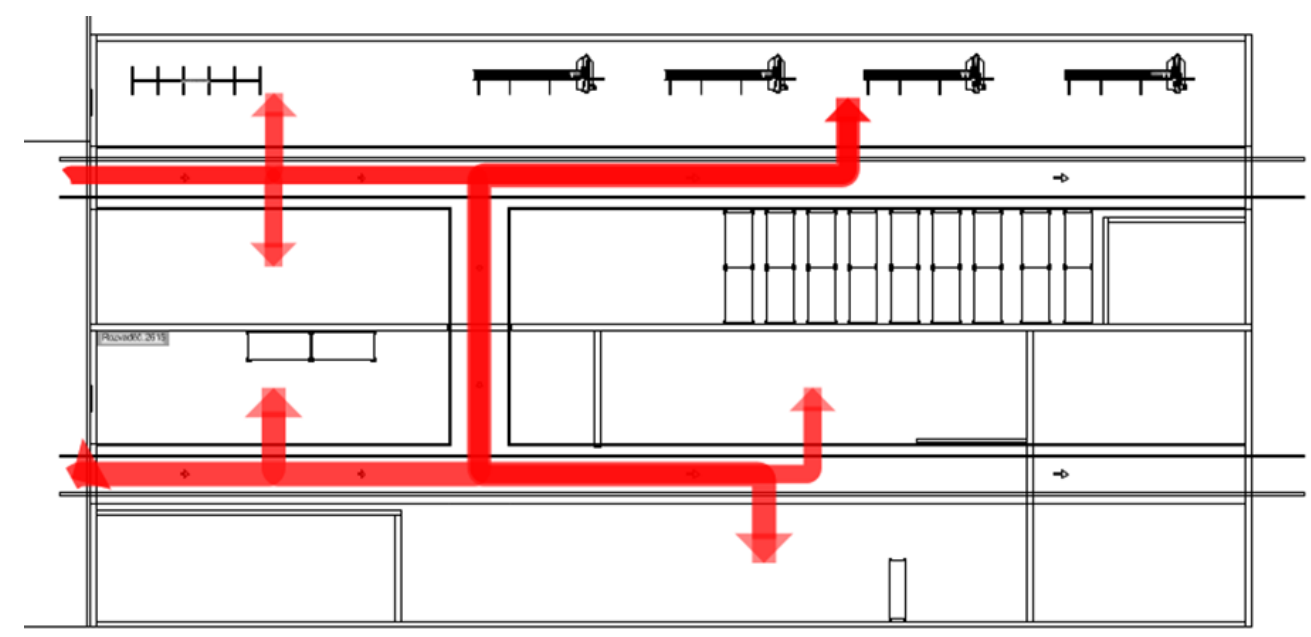

Obrázek 3 - Varianta $A$

\subsubsection{Varianta B - stroje naproti sobě}

Stroje jsou orientované do haly, ale rozděleně po 2 naproti sobě. Je nutné přesunout všechny policové regály. Dojde $k$ úspoře přechodů ven $z$ haly $a$ k úspoře $v$ manipulaci materiálu. Návrh je vidět na obrázku 4.

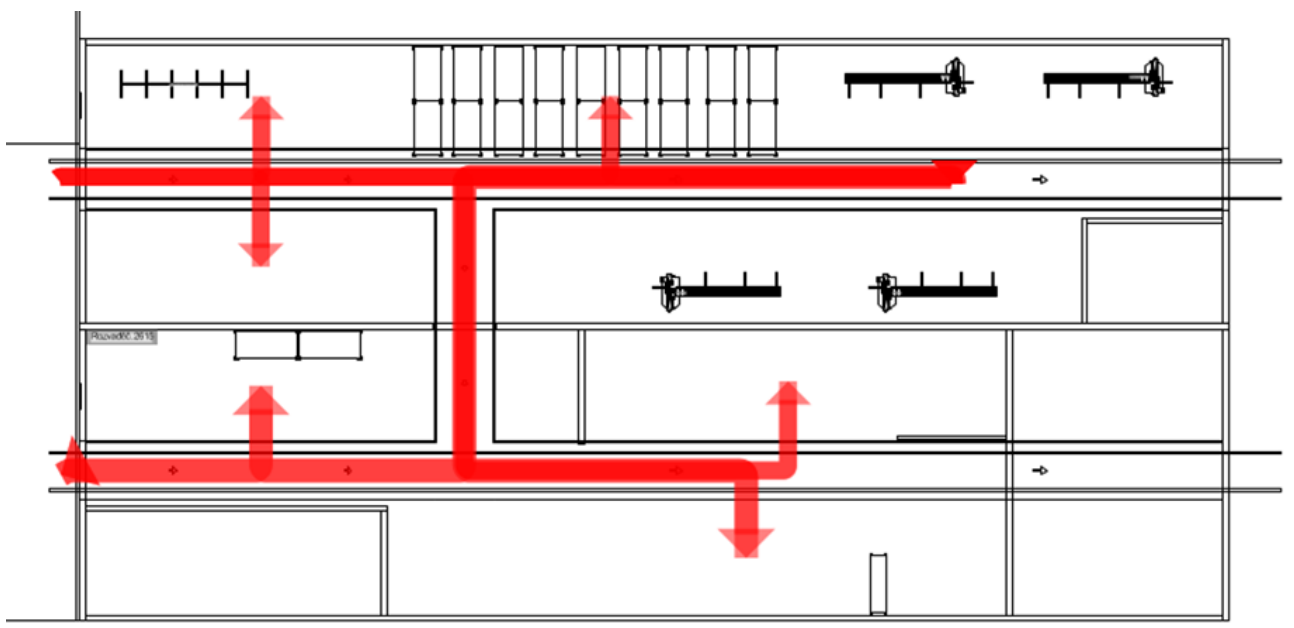

Obrázek 4 - Varianta $B$

\subsubsection{Varianta C - stroje skrz stěnu}

Došlo k výrazné změně, kdy stroje byly přesunuty do druhé lodi výrobní haly při ponechání orientace. Bylo nutné nejen přesunout policové regály, ale také vybourat otvory pro obsluhu a dopravníky. Toto uspořádání zlepšuje možnost zavážení materiálu a umožňuje přesun materiálu do první lodi, čímž se výrazně zkrátí potřebná manipulace i přechody a zároveň dojde ke zvýšení bezpečnosti na pracovišti. Návrh je zobrazen na obrázku 5. 


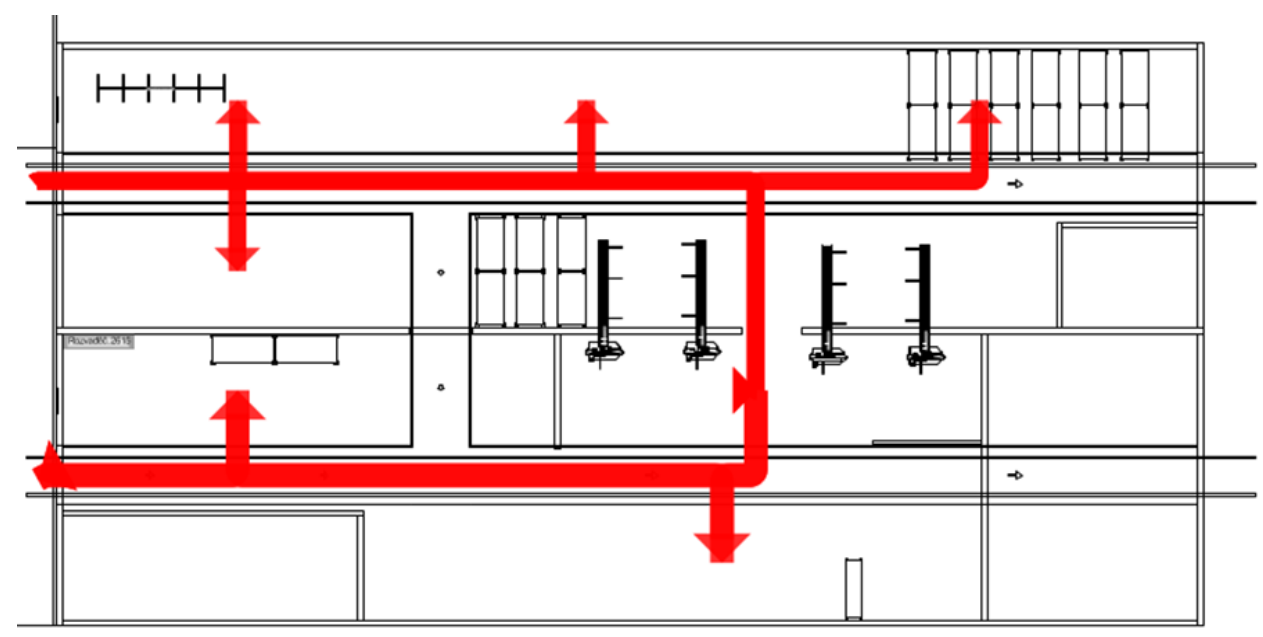

Obrázek 5 - Varianta C

\subsection{Hodnocení a výběr varianty}

Hodnocení variant a jejich výběr byl proveden na základě multikriteriálního hodnocení podle zvolených kritérií, jejichž významnost byla stanovena skupinou expertů z podniku. Výsledné hodnocení bylo provedeno metodou pořadové funkce a v grafu na obrázku 6 je znázorněno pořadí variant po vyhodnocení.

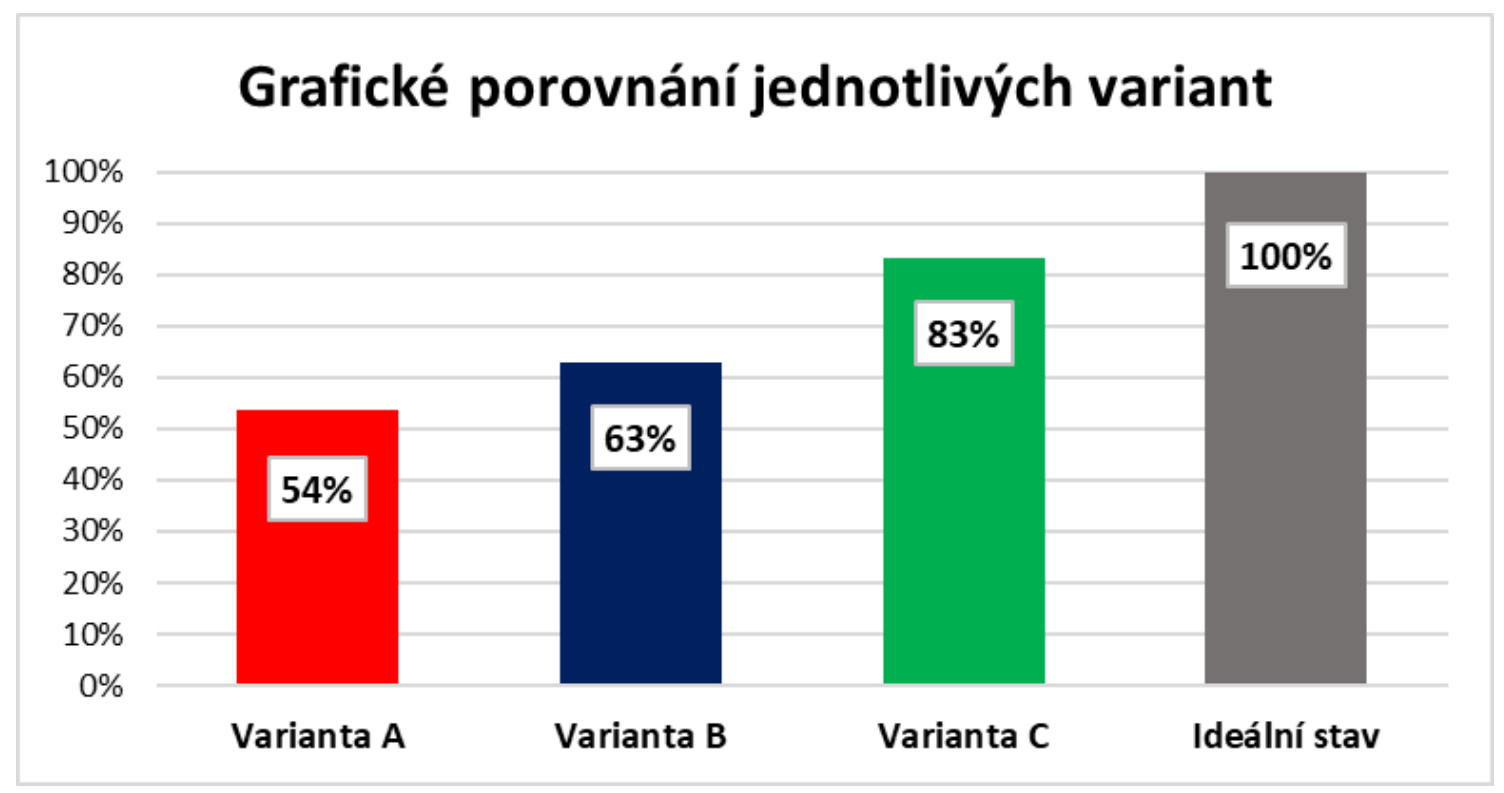

Obrázek 6 - Sloupcový graf s porovnáním jednotlivých variant

\subsection{Porovnání s původním stavem}

Pro přehlednost byl vytvořen graf na obrázku 7 , který znázorňuje procentuální porovnání jednotlivých kritérií nového prostorového uspořádání oproti původnímu stavu. Šipky označují, zda jde o minimalizační, šipkou dolů, či maximalizační kritérium, šipkou nahoru. 


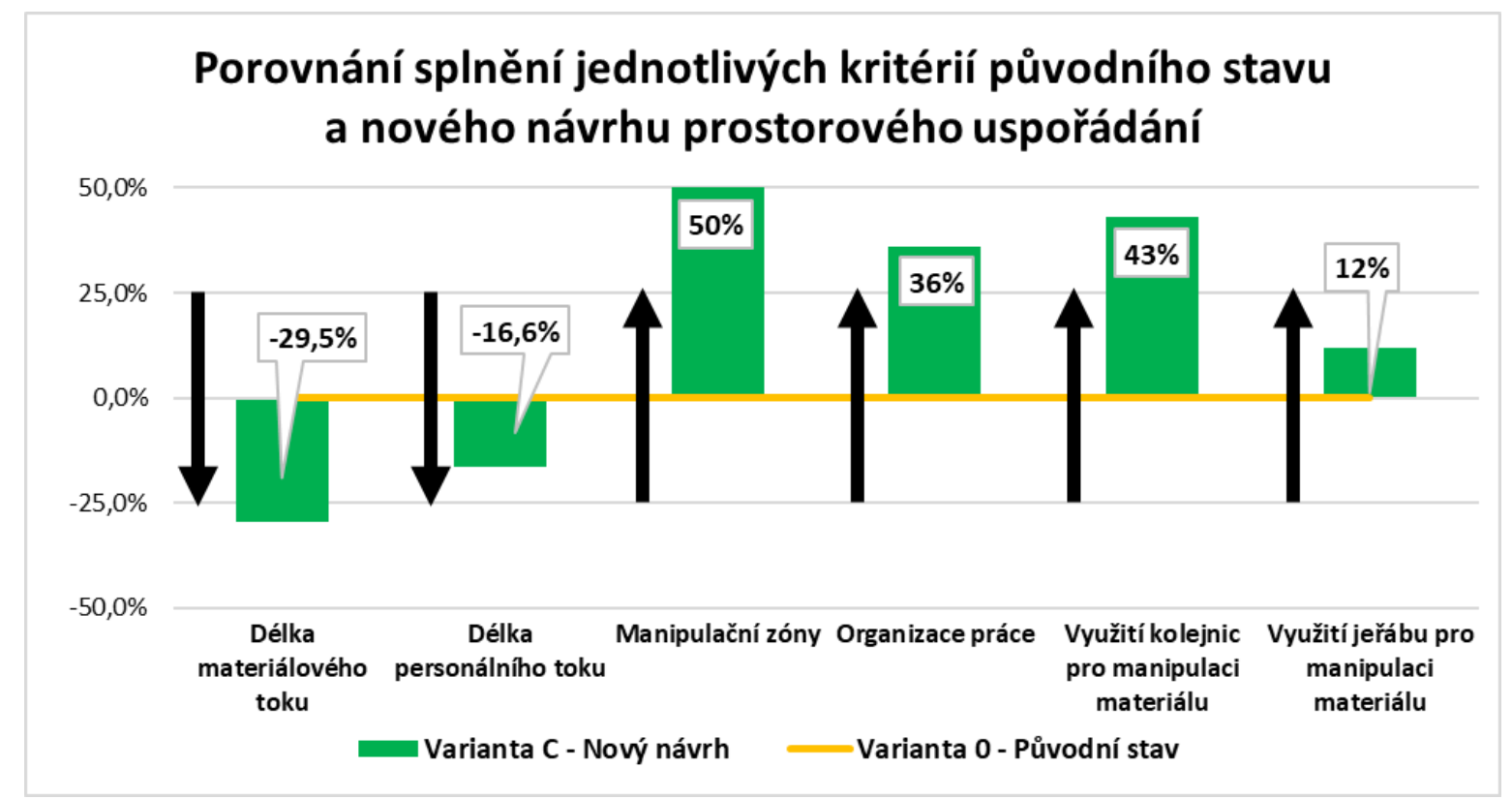

Obrázek 7- procentuální porovnání kritérií původniho a nového uspořádání

\section{Závěr}

Článek se zabývá oblastí návrhu nového prostorového uspořádání výrobní jednotky. Návrh byl tvořen $v$ souladu $s$ charakterem výroby a s požadavky podniku na zvýšení objemu výroby na pracovišti. Z pưvodních analýz, které se týkaly prostorových a časových studií, byly odhaleny určité problémy a stanovena kritéria pro multikriteriální hodnocení variant návrhu. Kritéria byla mezi sebou párově porovnána pro stanovení důležitosti těchto kritérií pro podnik. Důležitost kritérií byla stanovena pomocí váhy pro každé kritérium.

Dle definovaných nedostatků a kritérií byly vytvořeny 3 varianty nového návrhu prostorového uspořádání. Cílem nového návrhu bylo zavést nápravná opatření, která nedostatky eliminují nebo úplně odstraňují, a tím dosáhnout co nejlepšího hodnocení ve všech kritériích. Hodnocení variant probíhalo na základě metody pořadové funkce, kdy je určeno pořadí variant dle získaných hodnot $v$ jednotlivých kritériích. Dle tohoto hodnocení byla vybrána nejvhodnější varianta.

Nově navržený stav uspořádání výrobní jednotky byl poté porovnán $\mathrm{s}$ původním stavem. Dle porovnání $v$ rámci bylo zjištěno, že nový stav dosahuje zlepšení ve všech hodnotících kritériích. Došlo tedy ke zvýšení produktivity nového pracoviště oproti původnímu stavu. Výstupem je také grafické znázornění $2 D$ výkresu výrobní haly včetně 3D vizualizace.

\section{Poděkování}

Tento článek byl vytvořen za podpory interního grantu Západočeské univerzity v Plzni číslo SGS-2018-031 s názvem Optimalizace parametrů udržitelného výrobního systému. 


\section{Použitá literatura}

[1] Fotr, J., Švecová, L. Manažerské rozhodování: postupy, metody a nástroje. 3. vyd., Praha: Ekopress, 2016. ISBN 978-80-87865-33-0.

[2] Záček, V. Management podniku. 1. vyd., Praha: Nakladatelství ČVUT, 2009. ISBN 978-80-01-04370-7. 